\title{
DEVELOPING A TASK-BASED SYLLABUS BASED ON NEEDS ANALYSIS FOR MIDWIFERY AT UIN ALAUDDIN MAKASSAR
}

\author{
Dahniar \\ State University of Makassar \\ Badruddindabniar01@yahoo.co.id
}

\begin{abstract}
This research aimed to develop a Task-Based syllabus for midwifery students of Midwifery Study Program at UIN Alauddin Makassar. The research design used in this study was Research and Development (R \& D). Types of data obtained in this study were qualitative and quantitative. The qualitative data gained from interviewing students, graduate, and from the experts validation; meanwhile the quantitative data gained from the questionnaire which was distributed to the students. The instruments used in this study were questionnaire, interview guideline and rubric. The result of this research showed that 1) language needs of the students cover language skills and learning preferences. In language skills, speaking, listening, writing, reading are used often. In learning preferences, learning preferences in terms of learning English with others, others are study in small group, and study in big group, self study, study in pairs, while learning preferences in terms of learning by using teaching technique, study trough listening and speaking is mostly preferred by the students. 2) Language function used of graduate in the workplace is pregnancy, during pregnancy, good food for pregnant woman, diet in pregnancy, how to cut the umbilical cord, medical equipment. 3) The design syllabus based on the students' need. In this case, the researcher recommended a Task-Based Syllabus based on the students' need. The components of syllabus were validated. After validation, the experts pointed out that some components of the syllabus were developed well, whereas some components should be revised: materials, learning activities/task, and time allotment. Some of the materials were changed with the appropriate materials whih was correlated with the topic, individual practice was needed to be added to the learning activities, time allotments should be distributed proportionally, and then the sources should be added.
\end{abstract}

KEY WORDS: Task based syllabus, needs analysis, midwifery students.

\section{A. INTRODUCTION}

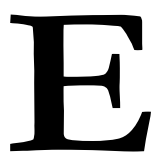

nglish for Specific purpose at the academic setting is known as English for Academic Purpose. It was subjected to the learners who need English for academic study such as English for medical study, English for nurse, English for midwifery and the like. Experience had shown that most university 
students need English as a key to success in their major disciplines, the learners were strongly urged to build up their English competences as a tool to gain access to information, and materials that did not exist in their own language. Therefore, it was expected that the institutional needs should in line with the needs of the majority of the students, namely to acquire information in their subject matter from any English literature. Hutchinson and Water (1989:6) stated that the expansion of specific, technical and economic activity led to a demand for an international language that is English. As the demand has been growing for ESP tailored to specific needs, ESP had been strongly focused on making materials relevant to target needs.

Concerning the importance of English to the students and made materials relevant to target needs, the researcher analyzed the syllabus which include of English subject need on Midwifery Study Program of UIN Alauddin Makassar. James Dean Brown (1995:35) stated that need analysis involves the gathering of information to find out how much the students already know and what they still need to learn. The goal was analyzed the appropriate syllabus for the midwifery students because English is offered in Midwifery Study Program with the consideration that the students' proficiency in this skill had a great effect on their academic and professional succes. By profession, midwifery students were required to possess good command of English.

The findings of the preliminary study indicated that the students consider that English subject was not so important. This leads them to be passive learners of English with poor motivation, and most of students were not interested to learn because the material still in general English, they had difficulties understanding most of the materials presented by lecturer because teaching and learning process was dominated by lecturer.

Part of the current was that the syllabus which used in midwifery study program is not well designed, because the components of syllabus in terms of learning activities, the instructional materials and media, time allotment, rating/evaluation were not stated clearly. Furthermore, it was also found that the subjects used by the lecturer had not been well organized and the language was too difficult for the students, most of the subjects are taken from the sources which were not suitable with students' proficiency. The subjects were integrated without variety in the activities so that the students had such a tedious experience of learning process. The current syllabus tends to focus on gramatical rules, expression, listening activities, report writing, most of these material could not cover what the students need from the course because it was too general, it made the students very confused because they were also hard to understand the explanation of the lecturer. 
Dahniar, Developing A Task-Based Syllabus Based on Needs Analysis For Midwifery ...

Considering the problems and factor analysis, the researcher viewed that it was very essential to give English subjects which was up-to-date and appropriate with the students' need as well as their English proficiency for the students of midwifery study program. Furthermore, the lecturer should prepare the subjects and found the source such as books which were appropriate with the students language need and proficiency. Therefore, it was expected that lecturers teach English for midwifery students or ESP which was relevant to students' need of the study and meet the English need. The lecturers should understand the diverse needs of students, decide to choose the teaching material based on the special needs of students. All lecturers had to be throughly familiar with their responsibilities, professional with special needs in English of the students. As educator, we were on a life-long journey to develop our skills and knowledge on meeting the needs of all our students and especially who need extra help. Huntchinson and Waters (1987) explained ESP as "an approach to language teaching in which all decisions as to content and method are based on the learner's reason and learning." Following on from this concept, it was essential to gain understanding of the needs of our learners. These three aspects of would be used to develop a Task-Based Syllabus.

\section{B. LITERATURE REVIEW}

\section{The Profile Of Midwifery at UIN Alauddin Makassar}

The Government of the Republic of Indonesia on the basis of democratic principles provides educational services in accordance with the aspirations of the nation and in line with the philosophy of the applicable legislation. Responding to the increasing demands of the society, the State Islamic Institute (IAIN) Alauddin Makassar by decision of the Minister of National Education No. 179/MPN/KL/ 2004 dated 10 December, 2004 and President regulations no. 57 of 2005 dated 10 October, 2005 institutionally developed into State Islamic University ( UIN ) Alauddin Makassar, the change was given permission to open new eight studies program, one of the program is the Faculty of Health which was composed of five departments:
a. Pharmaceutical Studies Program (S1)
b. Public Health Studies Program ( S1 )
c. Midwifery Studies Program (D3)
d. Nursing Study Program ( S1 )
e. The study program of Professional Nurses 


\section{Syllabus}

In regard of what syllabus is, McKey (1978: 11) states that a syllabus provides a focus for what should be studied, along with a rationale for how that content should be selected and ordered.

A good syllabus will account for at least five components. First, the goals and objectives of the course. Second, the instructional materials and media: instructional materials deal with what material being taught to the learners during the course. The materials should be in line with the learners' needs and interests. It also deals with the goals and objective of the course. In contrast, media deals with the media used in teaching and learning process in order to help the teachers to accomplish the goals and objectives of the course. It accounts for books, blackboard, LCD, computer/ laptop, disks, CD-Rom's, flash drives, lab supplies, and so forth. Third, the teaching and learning activities: It deals with what strategies being implemented in the teaching and learning activities such as discussion, role-play, presentation, lecture, service learning, cooperative learning, group projects, group grades, peer evaluation, practicum, and so forth. Fourth, assessment: it deals with how to evaluate the teaching and learning processes. It accounts for assignments, weight of each assignment or exam, kinds of papers or projects, format, due dates, kinds of exams due dates, reading assignments, due dates, rewrite and make-up policies, acceptability of handwritten work, grading criteria, and policy on late assignments. Fifth, time allotment: it deals with the duration of each material being taught, or how many meetings for each material.

Regarding to the approaches of syllabus design for foreign language teaching, Brown (1995:7) divides syllabus into seven classification; a) structural syllabus, b) situational syllabus, c) topical syllabus, d) functional situational syllabus, e) notional syllabus, f) skill-based syllabus, and g) task-based syllabus.

\section{Needs Analysis}

In general terms, need analysis (also called need assessment) refers to the activities involved in gathering that will serve as the basis for developing a curriculum that will meet the learning needs of a particular group of students. In the case of language program, those needs will be language related. Once identified, needs can be stated in term of goal and objectives which, in turn, can serve as the basis for developing test, material, teaching activities and evaluation strategies, as well as for reevaluating the precision and accuracy of the original needs assessment. Thus need assessment is an integral part of systematic curriculum building (Brown, 1995:35). 
A need analysis may be conducted for a variety of different users. For example, in conducting a need analysis to help revise the secondary school English curiculum in a country, the end users include: a) Curiculum officers in ministry of education, who may wish to use the information to evaluate the adequency of existing syllabus, curriculum. b) Teacher who will teach from the new curriculum. c) Learner who will be taught from the new curriculum. d) Writers who are preparing new textbooks. e) Testing personnel, who are involved in developing end-of-school assessments. f) Staff of tertiary institution who are interested in knowing what the expected level will be of students existing the schools and problems they face.

Needs analysis in language teaching may be use for a number of different purposes as stated by Richard (2001:52):

a. To find out what language skills a learner needs in order to perform a particular role, such as sales manager, tour guide or university students.

b. To help determine if an existing course adequately addresses the needs of potential students.

c. To determine which students from a group are most in need of training in particular language skill.

d. To identify a change of direction that people in a reference group feel is important.

e. To identify a gap between what students are able to do and what they need to be abe to do.

f. To collect information about a particular problem learners are experiencing.

\section{English for Specific Purposes}

According to Hutchinson and Waters (1987) see ESP as an approach rather than a product, by which they mean that ESP does not involve a particular kind of language, teaching material or methodology. In general, ESP can be subcategorized into two main types as Wello (1999:7) explained that the branches of ESP are EOP (English for Occupational Purpose) and EAP (Eglish for Academic Purpose). EOP involves mostly work-related needs and training while EAP involves academics and stdudy needs. Cutting between those is EST (English for Science and technology) which can refer to both work and study related needs. English for Vocational Purpose (EVP) is for those preparing for job training

ESP courses can be characterized too, but practice is common to find courses which the organizers wish to think of as ESP course but which do not seem to fit the agreeable criteria, therefore it is essential that the subject be addressed 
clearly based on the common ground and similiar perception and understanding among ESP practitoners-teachers, course designers/material writers and organizers.

\section{Midwifery English}

Midwifery English refers to the language used for midwifery which is familiarity with sources, necessary expression, material related to midwifery. For instance, greeting the patient, filling the admission, giving healthcare education, job interview, and so on, the goal is to achieve the ability of understanding midwifery concept the level of professional knowledge.

\section{METHOD OF THE RESEARCH}

Dealing with purpose of this research in providing English teaching materials for Midwifery Study Program, the design of this research was Research and Developmental (R\&D). Borg and Gall (1983:772) state research and development as a process used to develop and validate educational product. The argue that educational research and development can be achieved by developing new educational product and it aims to improve the quality of education. The subject of this research were the students and graduates of Midwifery Study Program at UIN Alauddin Makassar. The subject took from two groups. The first group were students who were still studying in midwifery study program at UIN Alauddin Makassar, and total number of the students were 73 . The second group was the midwifery college graduates who work in AWAL BROSS International Hospital and the lecturer of STIKPER GUNUNG SARI. The researcher used convenience sampling for midwifery study program graduates whoever available at the time. To obtain the data of this research, the researcher used three kinds of instruments; questionnaire, interview guideline, and rubric. The questionnaire given to the students who were still studying at the college and graduates who work in AWAL BROSS International Hospital and STIKPER GUNUNG SARI, while the interview to support the data from the questionnaire. The questionnaire used to identify the students' need in midwifery English teaching subjects to develop a Task-Based syllabus, and the rubric be given to expert to validate the final product.

\section{D.FINDINGS}

The findings of the research are summarized in terms of needs of the midwifery students and the graduate. The following is the data obtained from the questionnaire and the interview from the subject of research. 
1. The language needs of Midwifery Study Program Students at UIN Alauddin Makassar

a. English language use for Midwifery Study Program students at UIN Alauddin Makassar

Based on the questionnaire given to the students about the frequency of using English in the classroom, the table shows that all the language skills; listening, speaking, writing and reading are used at the rate of often categorized. Speaking (3.24) and reading (3.21) are used more often than listening (2.97) and writing (2.94) in the classroom.

Table 4.1 The frequency of using English in the classroom

\begin{tabular}{|c|c|c|}
\hline Skills & Total & Mean Score \\
\hline Speaking & 237 & 3.24 \\
\hline Listening & 217 & 2.97 \\
\hline Writing & 215 & 2.94 \\
\hline Reading & 235 & 3.21 \\
\hline
\end{tabular}

Besides identifying the frequency of using language skills in the classroom, it is also important to identify the difficulties of language skills used by the students. The following table shows that the students recognized that all the language skills speaking (2.94), reading (2.82), listening (2.79), and reading (2.79) fall into difficult category. As the following table:

Table 4.2 The Difficulties in Learning English

\begin{tabular}{|c|c|c|}
\hline Skills & Total & Mean Score \\
\hline Speaking & 215 & 294 \\
\hline Listening & 204 & 2.79 \\
\hline Writing & 204 & 2.79 \\
\hline Reading & 206 & 2.82 \\
\hline
\end{tabular}

\section{b. The Importance of language skills}

The four English language skills are very important for the students. Regarding that those language skills are integrated skills, they cannot be separated. Such as speaking skills cannot be separated from listening skills, and writing skill cannot be separated from reading skill. From the table below, it shows that listening 
(3.45), speaking (3.43), reading (3.41), and writing (3.34) fall into important category, As the following table:

Table 4.3 The importance of language skills

\begin{tabular}{|c|c|c|}
\hline Skills & Total & Mean Score \\
\hline Speaking & 251 & 3.43 \\
\hline Listening & 252 & 3.45 \\
\hline Writing & 244 & 3.34 \\
\hline Reading & 249 & 3.41 \\
\hline
\end{tabular}

Furthermore, regarding to the importance of English, most of the students took into account that English is very important to be success in carrier (3.65), to exchange information (3.54), to be successful in college (3.53), while some of the students assignment stated that as personal need $(3,50)$ and to get scholarship (3.47) taken into important level. As the table shows:

Table 4.4 The Importance of English

\begin{tabular}{|l|c|c|}
\hline & Total & Mean Score \\
\hline To be successful in college & 258 & 3.53 \\
\hline To be successful in carrier & 267 & 365 \\
\hline To exchange information & 259 & 3.54 \\
\hline To get scholarship & 254 & 3.47 \\
\hline As personal need & 256 & 3.50 \\
\hline
\end{tabular}

\section{c. The Learning Preferences of the students}

Learning preferences is about on how the students learn well and like the teaching activities or technique used by the teacher, and how the teachers select the appropriate materials that serve the students' need in learning. Each student about learning preferences and teaching activities are different. Learning preferences in terms of studying with others, it was found that study in small group (3.23), self study (3.12), study in pairs, (3.10), study in big group (3.04) which categorized as important level. These findings indicate that study in small group, self study, and study in pairs, study in big group should be taken into consideration in creating the activities to 
fulfill the learning preferences in learning English for Midwifery. Not only identifying the learning preferences in terms of the ways of learning with others, but also it was important to find out the students learning preferences in terms of the ways of learning by using the teaching equipment. As we can see on the table from the students' answer, it shows that study through listening while pronouncing (3.60) fall into very important category. This finding indicates that study through listening while pronouncing is more preferred than others such as study through reading, study through listening, study through reading while taking notes, study through repetition, and study trough memorizing and pronouncing which are categorized as the important ways of learning. In addition, that teaching English by using role plays and games are preferred also in learning English. Study through game (3.15) and study through role play (3.10) fall into important category should be taken into consideration in designing syllabus. As the following table

Table 4.5 The Learning and Teaching Activities that Mostly Preferred

\begin{tabular}{|l|c|c|}
\hline & Total & Mean Score \\
\hline Self study & 228 & 3.12 \\
\hline Study in pairs & 227 & 3.10 \\
\hline Study in small group & 236 & 3.23 \\
\hline Study in big group & 222 & 3.04 \\
\hline Study through listening & 243 & 3.32 \\
\hline Study through reading & 256 & 3.50 \\
\hline Study through listening and speaking & 263 & 3.60 \\
\hline Study through reading while making notes & 233 & 3.19 \\
\hline Study through repetition & 250 & 3.42 \\
\hline Study through memorizing and speaking & 247 & 3.38 \\
\hline Study through games & 230 & 3.15 \\
\hline Study through role play & 227 & 3.10 \\
\hline
\end{tabular}

\section{d. The language function needed by the Midwifery Study Program students at UIN Alauddin Makassar}

The language function needed by the students in the classroom fall into very important category such as pregnancy (3.64), during pregnancy (3.52), how to cut the umbilical cord (3.54). While getting to know each other (2.84), parts of body (2.78), when was your last period (3.05), where is the maternity clinic (3.16), direction (3.30), 
take a deep breath (2.97), good food for pregnant woman (3.38), diet in pregnancy (3.28), when could the pregnant woman meet midwife (3.02), medical equipment (3.38) are categorized as important for the students. Furthermore describing medical specialist $(2,49)$, telling current activity of patients (2.31), interview job (2.46), naming of pain (2.12), asking and giving suggestion (2.06) are categorized as less important. As the following table:

Table 4.6 The Language Function Needed by the Students in the Classroom

\begin{tabular}{|l|c|c|}
\hline & Total & Mean Score \\
\hline Describing medical specialist & 182 & 2.49 \\
\hline Telling current activity of patients & 169 & 2.31 \\
\hline Getting to know each other & 208 & 2.84 \\
\hline Parts of body & 203 & 2.78 \\
\hline Pregnancy & 266 & 3.64 \\
\hline When was your last period & 223 & 3.05 \\
\hline Where is the maternity clinic & 231 & 3.16 \\
\hline Direction & 241 & 3.30 \\
\hline Take a deep breath & 217 & 2.97 \\
\hline During pregnancy & 257 & 3.52 \\
\hline Good food for pregnant woman & 247 & 3.38 \\
\hline Diet in pregnancy & 240 & 3.28 \\
\hline How to cut the umbilical cord & 258 & 3.54 \\
\hline When could the pregnant woman meet midwife & 221 & 3.02 \\
\hline Medical equipment & 247 & 3.38 \\
\hline Interview job & 180 & 2.46 \\
\hline Naming of pain & 155 & 2.12 \\
\hline Asking and giving suggestion & 151 & 2.06 \\
\hline
\end{tabular}

These findings also supported from the interview of midwifery students. Most of the students didn't understand well about the difference between general English and English for Specific Purpose. It was caused the students were not taught English subject based on their need in Midwifery Study Program, they were taught general English which was include of full grammatical, the way to form a sentences. And they hoped that the lecturer taught them the specific English based on their need as Midwifery students. And in the term of the importance of English, some students considered that learning English was very important because Indonesia was going to pritrate country. 
2. The language needs of Midwifery Study Program graduates of UIN Alauddin Makassar

\section{a. The frequency using language skills in the workplace}

This part shows the use of English language in the workplace from graduates perspective. The graduates who works in International Hospital of AWAL BROSS), and work as lecturers in STIKPER GUNUNG SARI.

From the graduates' questionnaire, they mentioned that speaking (3.25), and listening (3.25)are used at the rate of often, while reading (1.75) and writing (1.75) are seldom used in the workplace. As the following table:

Table 4.7 The Frequency Using Language Skills in the Workplace

\begin{tabular}{|c|c|c|}
\hline Skills & Total & Mean Score \\
\hline Speaking & 13 & 3.25 \\
\hline Listening & 13 & 3.25 \\
\hline Writing & 7 & 1.75 \\
\hline Reading & 7 & 1.75 \\
\hline
\end{tabular}

In terms of using English in the workplace, the graduates stated that they often speak English either with Native speaker (3) or non native speaker (3.25), but they seldom communicate in English with Indonesian people (1.75) and communicate in English by phone (1.75). Furthermore, English is hardly ever used in speaking English with their boss (1.5), speaking English with their co worker (1) and communicate in English by email (1.25). As the table below:

Table 4.8 The use of English in the Workplace

\begin{tabular}{|l|c|c|}
\hline & Total & $\begin{array}{c}\text { Mean } \\
\text { Score }\end{array}$ \\
\hline Do you speak English with native speaker? & 12 & 3 \\
\hline $\begin{array}{l}\text { Do you speak English with non Native } \\
\text { speaker? }\end{array}$ & 13 & 3.25 \\
\hline Do you speak English with Indonesian people? & 7 & 1.75 \\
\hline $\begin{array}{l}\text { Do you speak English with patient in your } \\
\text { workplace? }\end{array}$ & 14 & 3 \\
\hline Do you speak English with your boss? & 6 & 1.5 \\
\hline $\begin{array}{l}\text { Do you speak English with your co worker? } \\
\text { Do you communicate in English with face to } \\
\text { face? }\end{array}$ & 4 & 13 \\
\hline
\end{tabular}




\begin{tabular}{|l|l|l|}
\hline Do you communicate in English by phone? & 7 & 1.75 \\
\hline Do you communicate in English by email? & 5 & 1.25 \\
\hline
\end{tabular}

\section{b. The Difficulties of English in Workplace}

Regarding to the difficulties faced by the graduates' questionnaire, it found that listening (3.25), speaking (3.5), and writing (3) are in difficult category, while reading (2.5) fall into less difficult for them.

Table 4.9 The difficulties of English in workplace

\begin{tabular}{|c|c|c|}
\hline & Total & Mean Score \\
\hline Listening & 13 & 3.25 \\
\hline Speaking & 14 & 3.5 \\
\hline Writing & 12 & 3 \\
\hline Reading & 9 & 2.5 \\
\hline
\end{tabular}

\section{c. The Importance of language skills}

The four English language skills are very important for the graduates. Regarding that those language skills are integrated skills, they cannot be separated each other. From the table below, it shows that listening (3.5), speaking (3.5), writing (3.25), and reading (3.25) fall into important category, As the following table:

Table 4.10 The importance of language skills

\begin{tabular}{|c|c|c|}
\hline & Total & Mean Score \\
\hline Listening & 14 & 3.5 \\
\hline Speaking & 14 & 3.5 \\
\hline Writing & 13 & 3.25 \\
\hline Reading & 13 & 3.25 \\
\hline
\end{tabular}

Furthermore, from graduates' view, English was at the rate of very important to be success in carrier (3.75). While, to be success in college (3.25), to get scholarship (3.25), to exchange information (3.5) are rate important category and less important as personal need (2.5). 
Dahniar, Developing A Task-Based Syllabus Based on Needs Analysis For Midwifery ...

Table 4.11. The importance of English

\begin{tabular}{|l|c|c|}
\hline & Total & Mean Score \\
\hline To be success in college & 13 & 3.25 \\
\hline To be success in carrier & 15 & 3.75 \\
\hline To exchange information & 14 & 3.5 \\
\hline To get scholarship & 13 & 3.25 \\
\hline As personal need & 10 & 2.5 \\
\hline
\end{tabular}

\section{d. The language function used in the workplace}

English language functions play an important role to make the students function adequately in the target situation. Here are the language functions that are mostly required in by the graduates in the workplace.

From graduates' perspective on the table, it shows that pregnancy (4), during pregnancy (4), good food for pregnant woman (4), diet in pregnancy (4), how to cut the umbilical cord (4), when could the pregnant woman meet midwife (3.75), medical equipment (4), getting to know each other (3.75) and interview job (3.75) were very important category. While parts of body (3.25), when was your last period (3.25), where is the maternity clinic (3.25), take a deep breath (3) fall into important level, furthermore direction (2.5) categorized as less important. And describing medical specialist (1.5), telling current activity of the patients (1.25), naming of pain (1.5), asking and giving suggestion (1.5) fall into not important. As the following table:

Table 4.12 The Language Function Used in The Workplace

\begin{tabular}{|l|c|c|}
\hline & Total & Mean Score \\
\hline Describing medical specialist & 6 & 1.5 \\
\hline Telling current activity of patients & 5 & 1.25 \\
\hline Getting to know each other & 15 & 3.75 \\
\hline Parts of body & 13 & 3.25 \\
\hline Pregnancy & 16 & 4 \\
\hline When was your last period & 13 & 3.25 \\
\hline Where is the maternity clinic & 13 & 3.25 \\
\hline Direction & 10 & 2.5 \\
\hline Take a deep breath & 12 & 3 \\
\hline During pregnancy & 16 & 4 \\
\hline Good food for pregnant woman & 16 & 4 \\
\hline
\end{tabular}


Volume I, Number 01, June 2015

\begin{tabular}{|l|c|c|}
\hline Diet in pregnancy & 16 & 4 \\
\hline How to cut the umbilical cord & 16 & 4 \\
\hline $\begin{array}{l}\text { When could the pregnant woman meet } \\
\text { midwife }\end{array}$ & 15 & 3.75 \\
\hline Medical equipment & 16 & 4 \\
\hline Interview job & 15 & 3.75 \\
\hline Naming of pain & 6 & 1.5 \\
\hline Asking and giving suggestion & 5 & 1.25 \\
\hline
\end{tabular}

These findings also supported from the interview of graduate students. Most of the graduate stated that they really needed English language when they passed the steps when they enrolled in their workplace, such us the graduate who work in International Hospital AWAL BROSS stated that she was asked to use English when they did the interview job, it showed that speaking is the important skill for graduate. And in the term of the use of English in workplace, the graduate from the Hospital AWAL BROSS told that, they often served a foreign patient, and communicated with them by using English, and sometimes in the big meeting with all staff it used English and Indonesian language. While, the graduate who work in STIKPER GUNUNG SARI stated that as the lecturer, in learning process they should using English such us, when they taught about life skill of midwifery students they had to watch a demonstration video which used English direction, and when they taught the midwifery term, medical term, most of the terms used English. Furthermore, in the term of the importance of English the graduated had the same opinion with the midwifery students, the graduates considered that learning English was very important because to find a job for a good carrier, and for looked for a scholarship. It showed that the graduates need English specially speaking skill.

Moreover, the last term about the recommended subject for midwifery students, the graduate asked the lecturer to teach the students about the English Specific Purpose for midwifery such as the vocabulary which correlated with the medical terms, focus on the task on midwifery, how to serve the patient, and all of the terms which correlated with the midwife task.

\section{E. DISCUSSION}

As the problem statement presented in the previous chapter, there are three research questions that will be answered, they are the language need, learning need and developing task based syllabus. As indicated by the result of the questionnaire and interview, the researcher found that all of the language skills; listening, speaking, 
reading, and writing are used in classroom. In the term of the frequency of using English in the classroom, speaking, listening reading, and writing are used at the rate of often in the classroom (table 4.1). From these findings the researcher concluded that, the language needed most by the midwifery are all language skill; speaking, listening writing and reading. Considering about the target situation where the midwife will use the language, so in this case, the lecturer should provide more many opportunities for speaking, listening, writing and reading in practice.

Furthermore, in terms of the language skills which are difficult for the students in table 4.2, the researcher found that the students recognized that all language skills; speaking, listening, writing and reading fall into difficult category. From these findings, the researcher considered that in teaching English of midwifery students, the lecturers should provide more rehearsals in applying the language skills; speaking, listening, writing and reading which are difficult for them in order that the students will be easier in learning English and master the language skills well.

For the first research question about the learning need, the researcher found that learning preferences and teaching activities should be considered in teaching and learning process. Learning preferences in terms of the ways of learning with others, the findings obtained from the students show that study in small group, study in big group, study in pairs and self study are preferred by the students. But among them the students rate study in small group in mean score higher than the others in table 4.5. Moreover, in terms of learning activities, the students stated that studying through listening and speaking is more preferred than studying through reading, reading while make a notes, studying through repetition, and studying through memorizing. Furthermore, according to the respondents in interview, learning English by using games and role plays, study with the feedback both of teacher and students should be taken into learning activities. So the students can practice all language skills directly with their friends, either in pairs or in a group.

For the second research question, in the term of the frequency using language skill in workplace in table 4.7, the researcher found that speaking and listening are used at the rate of often, while writing and reading fall into seldom categorized. This means that the language needs needed most by the graduates in the workplace is speaking and listening, particularly talking with the patients based on the interview of the graduates. Furthermore, in term of using English in workplace the graduates stated that they often speak English either with Native speaker or non native speaker but they seldom communicate in English with Indonesian people and communicate in English by phone while English is hardly ever used in speaking English with their boss, speaking English with their co worker and communicate in English by email. From 
these findings the researcher conclude that, the language needed most by the graduate are speaking and listening, considering about target situation where the midwife will use the language, such us the midwife is often communicate with native, non native and the foreign patient who cannot speak Bahasa specially in International Hospital AWAL BROSS, and the graduate needed speaking skill to deliver the midwifery term in learning process in AKPER GUNUNG SARI Makassar, but they hardly ever to communicate with their boss and co worker in English based on the interview.

For the third research question. After analyzing the students' language need and learning activities need and graduates' language need of Midwifery Study program at UIN Alauddin Makassar and also based on the general task of Midwife, the researcher developed a syllabus, it is include of Goals, Objectives, Material, English skill, Task, Assessment, Time allotment, And Resources and Media include topics. All of the contents focus on students' needs. So in this case, A Task-Based Syllabus is suitable for the students of Midwifery Study Program at UIN Alauddin Makassar. For more details about the suggested syllabus, the researcher designed a syllabus based on the students' needs that have been identified and validated by expert.

Based on the explanations above, the researcher infers that the existing syllabus applied in Midwifery Study Program at UIN Alauddin Makassar by the lectures have not been accordance with the students' needs. This statement are confirmed by the findings of the data through interview and questionnaire that the most needed skills by the students are speaking, reading, writing and listening while in the existing syllabus the materials taught tend to be more general; the syllabus only focuses on general English specially for structure. The result of this research is in line with the study result found by Ozlem AYAS and Yasemin KIRKGOZ (2013) which revealed that the four English skills should developed, in particular speaking and listening activities. The materials need to improved by integrating some skills with the students' field as nurse and midwifery students. And also it is correlated with the study found by Yanling Hwang (2011) which revealed that the English curriculum should integrate ESP teaching and general English teaching to students in medical field. Of course, this is unexpected thing since the students need to learn English based on their needs, in this case English for nursing, as Hutchinson and Waters (1987) stated that ESP is an approach to language teaching which aims to meet the needs of particular learners. Therefore, after analyzing the students' learning and language needs, the researcher developing a Task-Based Syllabus based on the students' need that can be used or applied by the lectures in general and specially for Midwifery Study Program at UIN Alauddin Makassar 
Dahniar, Developing A Task-Based Syllabus Based on Needs Analysis For Midwifery ...

\section{F. CONCLUSION}

Language needs of the students include; language skills and learning activities. In terms of language skills, all the four language skills; speaking, reading, writing, and listening are often used in the classroom. Speaking and reading are used little bit more often in the classroom, while speaking and reading are considered important by the respondents. The language skills needed most by the students are speaking, listening, writing and reading, that means in the learning process, the lecturer need to give more proportion in each language skills and give more rehearsal to the students. Furthermore, In terms of learning activities that the students need, studying by listening and pronouncing are more preferred by the students than the other. In addition, learning English by using games and role plays are also preferred by the respondents. Moreover, are also for learning with others are study in small group, self study, study in pairs, study in big group.

The language needs for graduates are, speaking and listening which are often when they talk with the patients, but they hardly ever communicate in English with the boss and the co-worker, similarly reading and writing are bardly ever used at work. The language needed by the graduates in the workplace are speaking and listening, then followed by reading and writing, as for the language function they are more related to pregnancy, during pregnancy, good food for pregnant woman, diet in pregnancy, how to cut umbilical cord, when could the pregnant woman consult with midwife, medical equipment, getting to know each other, and interview job are rated very important.

From the learning preference of the students, the researcher conclude that $\mathrm{A}$ Task-Based syllabus suitable for midwifery students, because in the learning process the midwifery students tend to choose the task-based learning such us, demonstration, work in pairs, discussion, role play. And the tasks are related with their profession as a midwife.

\section{G. SUGGESTION}

There are some suggestions addressed to people who concern with this research topic, they are: a) Curriculum designers of midwifery subjects, particularly in midwifery English curriculum, who should evaluate the adequacy of the existing syllabus, materials, and create a new syllabus that based on the students need. b) Midwifery instructors or teachers need to find out interesting ways in teaching English. It is suggested also that the syllabus should be based on the students' need. 
Volume I, Number 01, June 2015

\section{REFERENCES}

Borg, W.R \& Gall, M.D. 1983. Educational Research: An Introduction. Educational Research and Development. New York: Longman Inc.

Brown, J.D. 1995. The Elements of Language Curriculum: A Systematic Approach to Program Development. UK: Heinle \& Heinle.

Dick, W \& Carey, J. 2001. The systematic Design of Instruction. United States: Addison-Wesley Educational Publisher Inc.

Dubin, F., \& Olshtain, E. 1986. Course Design: Developing Programs and Materials for Language Learning. Cambridge: Cambridge University Press.

Duddley-Evans, T \& M. J. St. John. 1998. Developmental in English for Specific Purposes. Cambridge: Cambridge University Press.

Grafinger, Deborah J. (1988). Basics of instructional systems development. Alexandria: American Society for Training and Development.

Hwang, Y. 2011. Pedagogical Implications on Medical Students' Linguistic Needs. English Language Teaching, vol, 4(4), 2011.

Hutchinson, T \& Waters, A. 1987. English for Specific Purposes: A Learning-centered Approach. Cambridge: Cambridge University Press.

Krause, D.S. 2003. Need Analysis. (Retrieved on 15, February 2014 from http://linguistics.byu./edu/resources/volunteers/TESOLBYU NeedsAnaly sis.html.

Long, M. H., \& Crookes, G. (1992). The approaches to task-based syllabus design. TESOL Quarterly, 26 (1), 27-56.

Mazdayasna, G \& Tahririan, M.H. 2008. Developing a profile of the ESP of Iranian students: The case of students of nursing and midwifery. Journal of English for Academic Perposes, 7 (2008), 277-289.

McKey, S. 1978. Syllabus: Structural, Situational, and Notional. TESOL Newsletter, 12 (5), 11.

Ozlem, A \& Yasemin, K. 2013. The Academic and Vocational English Language Needs of the School of Health Students. Faculty of Educational Journal, 42(2013), 39-55.

Rabbini, R. \& Gakuen, B. 2002. An Introduction to Syllabus Design and Evaluation. The Internet TESL Journal, Vol. VIII, No. 5, May 2002, Retrieved from http://itesli.org/Articles/Rabbini-Syllabus.html, on August, $19^{\text {th }} 2014$.

Radina, A.N. 2012. Developing a Proposed Syllabus of EAP Reading for the Medical Students of Brawijaya University. 
Dahniar, Developing A Task-Based Syllabus Based on Needs Analysis For Midwifery ...

Ratna. 2013. Developing English for Specific Purposes (ESP) Course for Tour And Travel Students Based on Need Ananlysis.

Richard, J.C. 2001. Curriculum Development in Language Teaching. United Kingdom. Cambridge University Press. Unpublished Thesis. Malang:

Sukirman. 2013. Developing English Word Formation Materials for Undergraduate Students at State Uslamic University "Alauddin Makassar". Unpublished Thesis. Makassar: PPS Universitas Negeri Makassar. Graduate Program in English Language Teaching of Malang.

Toding, N. 2013. An Analysis of Teaching Material and Student's Need in Learning English at STAKN TORAJA. Unpublished Thesis. Makassar: PPS Universitas Negeri Makassar.

Wello, M. B. \& Amien, Hafsah. J. Nur. 1999. An Introduction to ESP (English for Specific Perposes). Badan Penerbit UNM

Yalden, J. 1987. Principles of Course Design for Language Teaching. Cambridge: Cambridge University Press.

Zhovu, A. A. 2009. What adult ESL learners say about improving grammar and vocabulary in their writing for academic purposes. Language Awareness, 18(1), $31-46$. 